Ritrýnd grein birt 15. desember 2019

\title{
Stuðningur við skólastjóra í grunnskólum: Staða og væntingar
}

\author{
Sigurbjörg Róbertsdóttir, Börkur Hansen og Amalía Björnsdóttir \\ Abstract $\rightarrow$ Um höfundana About the authors $\rightarrow$ Heimildir
}

Starfsumhverfi skólastjóra hefur breyst mjög mikið á undanförnum árum, orðið flóknara og starfið viðameira. Með breyttu starfsumhverfi og auknu álagi er stuðningur í starfi pýðingarmikill. Markmið pessarar rannsóknar var að kanna viðhorf skólastjóra í grunnskólum til stuðnings við pá í starfi og pörf peirra á stuðningi. Gögnum í rannsókninni var safnað með spurningalista sem sendur var til allra skólastjóra, 174 alls, og var svarhlutfall $67 \%$.

Meginniðurstaða rannsóknarinnar var að skólastjórar voru óánægðir með pann stuðning sem var í boði við upphaf ferils peirra, eingöngu 32\% eru ánægðir með pann stuðning sem peir fá nú í starfi og $47 \%$ peirra nefndu að pörf fyrir stuðning væri fullnægt að mestu leyti. Flestir nefndu að peir hefðu fengið mestan stuðning frá fjölskyldu eða vini við upphaf ferils síns og eru niðurstöður svipaðar við núverandi aðstæður. Skólastjórar voru sammála um að mikilvægt væri að njóta stuðnings í starfi en 95\% sögðu pað mjög eða frekar mikilvægt. Flestir töldu að fræðsluyfirvöld ættu að veita peim mestan stuðning en einnig kom fram að skólastjórar teldu sig purfa mestan stuðning við úrlausn erfiðra starfsmannamála og við stefnumótun. Svarhlutfall í rannsókninni var vel viðunandi og dreifing svara yfir landið nokkuð jöfn. Рað má pví álykta að pá mynd, sem dregin er upp hér, megi að öllum líkindum yfirfæra á skólastjóra í grunnskólum almennt. Af niðurstöðunum má álykta að margir skólastjórar kalli eftir víðtækari og markvissari stuðningi og pá aðallega frá fræðsluyfirvöldum.

Efnisorð: Skólastjórar, grunnskólar, stuðningur við upphaf starfsferils, stuðningur í starfi

\section{Inngangur}

Undanfarin misseri hafa starfsaðstæður kennara og álag í starfi verið talsvert í umræðunni hér á landi. Örar breytingar á starfsumhverfi skólastjóra, svo sem aukið álag á kennara og kennaraskortur, hafa áhrif á skólastjórnendur. Pegar bæjar- eða sveitarfélög ráđa skólastjóra er ætlast til pess að hann axli fulla ábyrgð á lögbundnum verkefnum frá fyrsta degi, sé faglegur leiðtogi, kynnist skólamenningunni og sinni öllum öðrum verkefnum. Nýr skólastjóri parf að finna út úr hvernig á að ráđa fólk, hverju parf að skila til launadeildar, hvernig á að sampykkja reikninga og gera stundatöflur, svo dæmi séu tekin um pau fjölmörgu verkefni sem parf að sinna. Á sama tíma parf hann að kynnast skólabragnum og starfsfólkinu. Staða nýrra skólastjóra er pví ekki ólík pví sem Lee (2015) lýsir í rannsókn sinni par sem nýi skólastjórinn mætir á svæðið og næstum pví allt fyrsta árið fer í að ráða fram úr hlutunum, kynnast skólamenningu og styrk- og veikleikum starfsfólksins. 
Maslach, Schaufeli og Leiter (2001) benda á að streita, álag og skortur á stuðningi geti leitt til kulnunar í starfi. Detta getur einnig leitt til pess að skólastjórar veikist eða snúi sér að öðrum störfum. Dæmi eru um að íslenskir skólastjórar hafi hætt eftir nokkur ár í starfi og pá jafnvel snúið aftur til kennslustarfa. Einnig eru dæmi um að skólastjórar fari í löng veikindaleyfi. Margt bendir til að skólastjórastarfið pyki ekki vera eins eftirsóknarvert og áđur og umsóknum um skólastjórastöður hefur fækkað (Evans, 2010; Fink og Brayman, 2004; OECD, 2014; Pont, Nusche og Moorman, 2008). Á Íslandi má sjá vísi að sömu próun. Svo virðist sem færri sæki nú um pær stöður sem auglýstar eru og víða parf að framlengja umsóknarfresti, jafnvel á höfuðborgarsvæðinu (Jakob Bjarnar, 2016). Árið 2015 var greint frá pví að fjórir nýir skólastjórar hefðu verið ráđnir í Reykjavík. Um hverja stöđu af pessum fjórum voru umsækjendur á bilinu 20-26 (Fjórir skólastjórar ráđnir í Reykjavík, 2015). Árið 2016 var umsóknarfrestur um stöđu skólastjóra við Melaskóla framlengdur vegna pess að aðeins fimm höfðu sótt um pegar upphaflegi fresturinn rann út. Tólf sóttu um eftir að umsóknarfrestur hafði verið framlengdur (Jakob Bjarnar, 2016). Vorið 2017 var auglýst eftir nýjum skólastjóra til starfa í einum skóla Reykjavíkurborgar og sóttu aðeins níu um pá stöðu (Reykjavíkurborg, 2017). Af pessu mætti draga pá ályktun að vísbendingar séu um svipaða próun hér á landi og annars staðar, pað er að æ færri líti á pað sem eftirsóknarvert starf að vera skólastjóri.

Boerema (2011) bendir á að brýnt sé að skólastjórar fái góđan stuðning í starfi við upphaf ferils síns og pegar fram í sækir. Að hans mati er góður stuðningur við stjórnandann lykilatriði til að hann haldist og próist í starfi. Dannig má að mati Boerema (2011) koma í veg fyrir að skólastjóri upplifi að honum sé kastað út í djúpu laugina án pess að kunna að synda og án kúts og korks og purfi sífellt að vera að reka sig á hlutina og finna upp hjólið í hvert sinn sem vandamál banka á dyr. Đað er pví áhugavert að kanna hvernig stuðningi er háttað við skólastjóra í íslenskum grunnskólum, bæði við upphaf starfsferils og við núverandi aðstæður.

\section{Stuðningur við skólastjóra}

\section{Starfsumhverfi}

Talsvert hefur verið fjallað um breytingar á hlutverki skólastjórnenda. Anna María Skúladóttir (2015) og Fullan (2014) benda til dæmis á að ábyrgð skólastjóra hafi aukist mjög síðustu 20 árin og starfið orðið flóknara. Samhliða pessari próun segir Fullan (2014) að í allri stefnumörkun komi fram að skólastjórar eigi að vera faglegir leiðtogar og reka óaðfinnanlega skóla. Deir eigi að vera sýnilegir, tengjast starfsmönnum, nemendum, foreldrum og samfélaginu, innleiða nýjar stefnur og leiða kennarana til framfara. Pessar aðstæður auki enn frekar á vinnuálag og pá ábyrgð sem hvíli á herðum skólastjóra.

Vísbendingar eru um að starfsánægja skólastjóra fari minnkandi. Fullan (2014) greinir til dæmis frá pví að frá árinu 2008 til 2014 hafi hlutfall bandarískra skólastjóra sem segjast vera ánægðir í starfi lækkað úr 68\% í 59\%. Rannsóknir Fink og Brayman (2004) og Hargreaves og Fink (2006) benda einnig til pess að auknar kröfur og minnkandi starfsánægja geti leitt til pess að skólastjórar hætti störfum fyrr en áđur gerðist. Íslenskar rannsóknir lýsa svipuðum aðstæðum; fjölgun verkefna og að stjórnendur eigi oft í erfiðleikum í starfi, meðal annars við að ná utan um mikilvæg verkefni og forgangsraða peim (Anna María Skúladóttir, 2015; Börkur Hansen, Ólafur H. Jóhannsson og Steinunn Helga Lárusdóttir, 2008). Í rannsókn Barkar Hansen og Steinunnar Helgu Lárusdóttur (2014) á starfsháttum í grunnskólum kom fram að skólastjórar vildu veita meiri leiðsögn og stuðning við kennslu en tímaskortur kæmi í veg fyrir pað hjá flestum. Meiri áhersla var pví lögð á aðra pætti starfsins og sat faglegur páttur pess á hakanum prátt fyrir vilja skólastjóra til að sinna honum.

Birna Sigurjónsdóttir og Börkur Hansen (2014) benda á að fjöldi nýrra verkefna hafi bæst við starfsemi grunnskóla á síðustu árum og að mörg peirra hvíli á herðum skólastjóra. Degar rýnt er í lög og reglugerðir kemur svipað í ljós. Með lögum um grunnskóla nr. 91/2008 var skólum til 
að mynda gert að sinna innra mati og einnig að sjá til pess að ytra mat yrði framkvæmt reglulega af sveitarfélögum og ráđuneyti. Ýmislegt fleira hefur bæst við störf skólastjóra, svo sem breytt umhverfi í mannaráđningum vegna stjórnsýslulaga nr. 37/1993, ný verkefni vegna upplýsingalaga nr. 140/2012, örar breytingar á kjarasamningum kennara (Kjarasamningur Sambands íslenskra sveitarfélaga og Kennarasambands Islands vegna Félags grunnskólakennara, 2018) og ný lög um persónuvernd og vinnslu persónuupplýsinga nr. 90/2018. Pessu til viðbótar má nefna erindi frá ýmsum opinberum aðilum um innleiðingu á lögum og reglugerðum, svo sem lögum um aðbúnað, hollustuhætti og öryggi á vinnustöðum nr. 46/1980, lögum um stöðu íslenskrar tungu og íslensks táknmáls nr. 61/2011 og lögum um jafna stöðu og jafnan rétt kvenna og karla nr. 10/2008, svo ekki sé minnst á nýja námskrá og nýtt námsmat (Mennta- og menningarmálaráđuneyti, 2013). Öll framangreind verkefni og nýtt verklag eru nú hluti af hefðbundnu skólastarfi.

\section{Mikilvagi stuðnings}

Vaxandi áhyggjur eru af pví að stétt skólastjóra sé að eldast, tíð skólastjóraskipti séu algeng og að allmargir skólastjórar hætti eftir stuttan tíma í starfi (Hargreaves og Fink, 2006; Meyer, Macmillan og Northfield, 2011) auk pess sem skólastjórar skipti oftar um starfsvettvang en ádur (Evans, 2010; Fink og Brayman, 2004). Eins og Meyer o.fl. (2011) benda á geta tíð skólastjóraskipti haft neikvæð áhrif á starfsfólkið, árangur nemenda og stöðugleika í skólastarfinu. Hargreaves og Fink (2006) segja að umsóknum um skólastjórastöður hafi fækkað bæði í Norður-Ameríku og annars staðar í heiminum. Á Íslandi má sjá vísi að sömu próun; svo virðist sem færri sæki nú um pær stöður sem auglýstar eru og víða parf að framlengja umsóknarfrest, jafnvel á höfuðborgarsvæðinu (Jakob Bjarnar, 2016).

Af framangreindu má draga pá ályktun að skólastjórastarfið pyki ekki vera eins eftirsóknarvert og áður og mikilvægt sé að veita starfandi skólastjórum stuðning í umhverfi sem verður sífellt flóknara. Stuðningur við skólastjóra getur verið formlegur og óformlegur. Formlegur stuðningur er pá utanaðkomandi, t.d. skipulagður af fræðsluyfirvöldum, sveitarfélögum eða öðrum aðilum. Sem dæmi má nefna skipulega starfspróun, formlega framhaldsmenntun, faglega handleiðslu, mentoring, pjálfun nýrra stjórnenda og ýmiss konar námskeið eða fyrirlestra sem skólastjórar sækja. Óformlegur stuðningur er pá hins vegar stuðningur sem skólastjórar sækja sér sjálfir eða skapa aðstæður fyrir. Par má nefna jafningjastuðning, að koma sér upp sérstökum bandamanni, óformleg samtöl og aðra aðstoð frá fagaðilum ýmiss konar (Honig, 2012; Mendels, 2017).

Boerema (2011) bendir einmitt á mikilvægi pess að styðja stjórnendur bæði á formlegan og óformlegan hátt pegar peir stíga sín fyrstu skref og reyna á eigin skinni pað sem peir hafa lært um starfið. Í rannsókn hans kom fram að margir nýir skólastjórar upplifðu sig einangraða á vinnustaðnum og einmana. Bauer og Silver (2018) rannsökuðu upplifun nýrra stjórnenda á einangrun í starfi og áhrif pess á aðra pætti. Einangrun í starfi er ekki aðeins skilgreind landfræðilega eða sem pað að vera eini stjórnandinn í skólanum heldur einnig sú upplifun að skólastjóri hafi engan að leita til innan eða utan skólans og purfi að taka ákvarðanir einn. Peir komust að pví að einangrun í starfi hafði bein og óbein áhrif á löngun skólastjóra til að hætta; með aukinni einangrun töluðu skólastjórarnir frekar um að peir hefðu íhugað að hætta. Óbein áhrif einangrunar komu einnig fram í upplifun peirra á eigin skilvirkni, starfsánægju og kulnun.

Stuðningur skiptir máli til að draga úr einangrun og aðili sem styður nýjan skólastjóra í starfi getur rofið einangrun hans og veitt faglega leiðsögn svo að sá nýi finni sína eigin rödd og stefnu (Boerema, 2011). Samkvæmt Honig (2012) getur stuðningur fræðsluyfirvalda við skólastjóra leitt til umbóta í skólastarfi og bætt bæði kennslu og stjórnunarhætti skólastjóra. Óraunhæft sé að öll leiðsögn eða handleiðsla sé á höndum samstarfsfélaga eða annarra skólastjóra, sem eru jafnan störfum hlaðnir. Sveitarfélög eða fræðsluyfirvöld verði pví að koma að pessum málum með formlegum hætti, efla skólastjórnendur í starfi og styðja pá eftir markvissum leiðum. 
Mendels (2017) lýsir pví hvernig fræðsluyfirvöld í sex fræðsluumdæmum í Bandaríkjunum hafa breytt hlutverki sínu úr pví að vera eftirlitsaðilar, par sem viss tortryggni ríkti á milli yfirvalda og skólastjóra, yfir í að vera helstu stuðningsaðilar skólastjóra. Skólastjórar fá nú betri leiðsögn í pví hvernig á að leiðbeina um nám og kennslu, hvernig á að stýra stofnuninni og hvernig á að byggja upp skólabrag. Deir fá reglulega skýrslu frá fræðsluyfirvöldum sem er byggð á heimsóknum og skoðunum allt skólaárið og áhersla er lögð á að peir eflist í starfi. Dað skiptir máli hvernig leiðsögn og stuðningur fræðsluyfirvalda er hugsaður, að markmiðið sé að efla og styrkja skólastjóra sem faglega leiðtoga og stjórnendur frekar en að hafa með peim eftirlit.

Í Kanada hafa verið gerðar metnaðarfullar rannsóknir á störfum skólastjóra og gefnar út handbækur til að styrkja pá í starfi og draga úr einangrun peirra (The Alberta Teachers' Association, 2018). Dá hafa verið gefin út viðmið um störf skólastjóra sem eru notuð við ráðningar. Skólastjórar geta einnig nýtt pessi viðmið til að efla sig og próast í starfi (Alberta Government, 2018). Hið sama hefur verið gert í Ástralíu, par sem lögð er áhersla á tiltekin svið skólastjórastarfsins (Australian Institute for Teaching and School Leadership, 2011). Slík viðmið styrkja stöðu skólastjóra og gefa peim tækifæri til að próast í starfi og setja skýr viðmið um pað til hvers er ætlast af peim.

Nokkrar rannsóknir og kannanir á stuðningi við skólastjóra hafa verið gerðar hér á landi. Í meistararitgerð Ingibjargar Magnúsdóttur (2013) var t.d. reynt að varpa ljósi á pann stuðning sem stæði nýjum skólastjórum til boða fyrsta starfsárið og skoða hvernig hann nýttist peim. Helstu niðurstöður hennar voru pær að stuðningur við skólastjóra skipti miklu máli, bæði faglegur og persónulegur, og að hann gæti verið af ýmsum toga; frá fræðsluyfirvöldum, samstarfsfólki innan skólans og öðrum skólastjórnendum innan og utan skólans. Einnig kom fram að stuðningurinn væri oft ómarkviss og réðist einkum af pví að hve miklu leyti stjórnendur bæru sig eftir honum. Að sömu niðurstöðum komst Sigríður Margrét Sigurðardóttir (2018), en peir skólastjórar sem hún ræddi við töldu að fræðsluyfirvöld pyrftu að axla meiri ábyrgð á stuðningi við pá; hann ætti аð vera markvissari og betur lagaður að aðstæðum hvers og eins. Í meistararitgerð Gerðar Ólínu Steinpórsdóttur (2014) kom fram að 70\% grunnskólastjóra sögðust sjaldan eða aldrei hafa fengið stuðning fyrsta starfsárið og aðeins 19\% sögðust alltaf eða oft hafa fengið stuðning fyrsta árið. Pá kom fram að $42 \%$ grunnskólastjóra sögðust alltaf eða oft fá stuðning frá fræðsluyfirvöldum og $31 \%$ sagðist sjaldan eða aldrei fá slíkan stuðning.

Samkvæmt niðurstöðum TALIS-rannsóknarinnar (OECD, 2014; Ragnar F. Ólafsson, 2014) eru skólastjórar á Íslandi virkari í starfspróun og eiga meiri samskipti við aðra skólastjóra en skólastjórar í öðrum löndum. Hlutfall peirra skólastjóra sem segjast vera virkir að sækja námskeið og fara í vettvangsheimsóknir í aðra skóla er 94\% og segjast peir verja í pað um sjö dögum á ári. Hlutfall íslenskra skólastjóra sem segjast hafa haft samband við skólastjóra annarra skóla oft eða mjög oft síðastliðna 12 mánuði er 67\% en meðaltalið í könnuninni er 62\% (OECD, 2014; Ragnar F. Ólafsson, 2014).

Samkvæmt TALIS 2018 er hærra hlutfall skólastjóra á Íslandi sem hefur sótt námskeið ýmiss konar en á Norðurlöndunum. Í samanburði við OECD og TALIS-löndin er mun meiri pátttaka hér, að meðaltali, í ráđstefnum um menntamál og meiri pátttaka í tengslanetum skólastjóra um starfspróun. Aftur á móti taka íslenskir skólastjórar talsvert minni pátt í formlegu námi sem lýkur með prófgráđu (Ragnar. F. Ólafsson, 2019).

\section{Stuðningur og pjálfun nýrra stjórnenda}

Service, Dalgic og Thornton (2016) benda á að ýmsar rannsóknir hafi leitt í ljós að nýir skólastjórar séu ekki nægjanlega vel undirbúnir undir starf skólastjóra og pað komi niður á stjórnunarháttum og pví hve lengi viðkomandi endist í starfi. Lítið er gert í pví að pjálfa nýja skólastjóra markvisst til leiðtogastarfa en ýmis lönd hafa pó gert tilraunir með slíkt, svo sem Nýja-Sjáland og Bandaríkin. 
Pont o.fl. (2008) benda á í skýrslu sinni fyrir OECD hve nauðsynlegt pað sé að undirbúa skólastjóra framtíðarinnar vel. Bush (2018) bendir á að pjálfun nýrra stjórnenda geti oft verið ómarkviss. Petta sé jafnvel aðeins eitt skipti par sem yfirvöld eða fyrrum skólastjóri setur hinn nýja inn í starfið. Detta eina skipti snýst pá jafnan eingöngu um pað að afhenda lykla og setja nýja skólastjórann inn í tölvukerfið. Betri leið til að pjálfa nýjan skólastjóra væri að gera pað yfir lengri tíma og gefa honum pannig tækifæri til að próa sig sem stjórnanda og fá pá aðstoð sem hann parfnast. Bush bendir á að slík pjálfun geti falið í sér marga pætti, svo sem handleiðslu, ýmiss konar pjálfun og aðstoð við starfspróun.

Nokkur lönd undirbúa tilvonandi skólastjóra með formlegum undirbúningi ádur en peir taka við stjórn skóla (Service, Dalgic og Thornton, 2016). Lee (2015) bendir pó á að pessar áætlanir geri ekki allar rád fyrir persónulegri próun skólastjórans og snúist frekar um hagnýta pætti skólastjórnunar, eins og hvernig eigi að gera stundatöflur og sjá um bygginguna. Lee bendir einnig á að pað sé mun vænlegra til árangurs að nýi skólastjórinn dvelji í ákveðinn tíma með fráfarandi skólastjóra til að kynnast starfinu, skólabragnum og starfsfólkinu.

Handleiðsla er skilgreind sem ferli par sem sá sem piggur handleiðsluna leitast við að hámarka hæfni sína, bæði persónulega og faglega, með ígrundun og skapandi hugsun (International Coach Federation, 2018). Whitmore (2017) talar um að handleiðsla eigi að hámarka mögulega hæfni pess einstaklings sem nýtur handleiðslu. Handleiðsla snýst meira um að hjálpa einstaklingi að læra en að kenna honum. Sá sem nýtur handleiðslu lærir pannig betur að kljást við aðstæður á vettvangi og beita pví sem hann lærir á hagnýtan hátt.

Samkvæmt Reyes (2003) getur handleiðsla verið með mismunandi hætti, svo sem einstaklingsbundin handleiðsla, jafningjahandleiðsla og hóphandleiðsla. Formleg handleiðsla er byggð á formlegum samningi á milli pess sem tekur að sér handleiðsluna og pess sem piggur hana og fer fram á ákveðnum tíma. Óformleg handleiðsla er pegar jafningjar eða starfsfélagar hittast. Pá er annar jafnvel með meiri reynslu en hinn, hefur fengið pjálfun í að handleiða og leiðbeinir peim sem minni reynsluna hefur. Aguilar, Goldwasser og Tank-Crestetto (2011) segja að margir af peim skólastjórum sem peir ræddu við um handleiðslu hafi talað um hve vel hún nýttist peim. Dá bendir rannsókn Ohrt, Prosek, Ener og Lindo (2015) til pess að fagfólk sem nýtir sér handleiðslu, hóphandleiðslu eða einstaklingshandleiðslu axli meiri ábyrgð á eigin lífi og að handleiðsla geti verið forvörn gegn kulnun.

Mentoring er náskyld handleiðslu en handleiðsla er aðallega verkefna- og árangursmiðuð á meðan mentoring lýtur meira að pví að byggja upp persónulega hæfni og virkja eigin visku auk pess að nýta innsæi pess sem leiðsögnina veitir (Leadership Thoughts, 2018). Retelle (2010) bendir á að mentoring lúti sömu lögmálum og handleiðsla og traust verði að ríkja á milli pess sem er mentor og „lærlingsins“. Mentorinn gefur peim sem hann styður ráð um hvernig best sé að próa persónulega hæfni í erfiðum aðstæðum eða verkefnum. Hann veitir lærlingnum tækifæri til að vaxa í starfi með pví að rýna í aðstæður hans og nýta sér pá pekkingu og reynslu sem hann sjálfur hefur aflað sér. Mentoring getur bæði verið formleg og óformleg. Sú formlega er pá skipulögð fyrir fram, til dæmis af fræðsluyfirvöldum, en hin óformlega sprettur jafnan upp úr faglegu sambandi tveggja aðila. Daresh (2004) segir pað ekki vera hlutverk mentors að kenna peim sem leitar til hans praktísk atriði eins og stundatöflugerð, hvernig meta eigi kennara, skipuleggja fundi með foreldrum eða önnur tilfallandi dagleg verkefni, heldur hvetur mentorinn lærlinginn til að nota eigin hæfni og verðleika til leysa pau mál sem um ræðir. Góður mentor er pví líklegri til að spyrja spurninga en að veita svör (Daresh, 2004).

Раð að eiga sérstakan bandamann (e. critical friend) er enn einn páttur sem getur nýst sem stuðningur við skólastjóra. Swaffield (2004) bendir á að slíkur stuðningur hafi pekkst lengi og svipi mjög til stuðnings af mentor. Swaffield segir að samband skólastjóra og sérstaks bandamanns byggist á pví að sá fyrrnefndi eigi vin sem spyr áleitinna spurninga, útvegar gögn sem hægt er að skoða betur og gagnrýnir sem vinur. Баð að eiga sérstakan bandamann er ytri stuðningur sem í 
sinni bestu mynd getur styrkt leiðtogafærni skólastjóra og stuðlað að skólapróun og betra skólastarfi. Sérstakur bandamaður getur verið jafningi eða sérfræðingur sem aðstoðar við ákveðin verkefni. Bandamaðurinn parf að hafa ákveðna kosti, eins og að nota virka hlustun, spyrja spurninga, fylgjast með á staðnum ásamt pví að sýna virðingu, samúð, heiðarleika, sjálfsöryggi, bjartsýni og innsæi. Marsh (2010) bendir á að pegar fáar stuðningsleiðir séu í boði geti petta verið lausn fyrir marga stjórnendur. Pardini (2000) bendir á að fjölmargir hafi nýtt sér pað að leita til sérstakra bandamanna og sé reynsla peirra góð af slíku fyrirkomulagi. Sérstakur bandamaður parf ekki endilega að vera einn einstaklingur heldur getur petta verið hópur fólks sem aðstoðar við að leysa úr flóknum málum eða kemur með sérstaka sýn á stöðu mála.

\section{Markmið}

Skólastjórar starfa í flóknu og margbreytilegu umhverfi sem tekur sífelldum breytingum með auknum kröfum og verkefnum. Við slíkar aðstæður er jafnan erfitt að forgangsraða verkefnum og sinna pví sem mestu máli skiptir. Ýmsar vísbendingar eru um að ánægja skólastjóra í starfi fari minnkandi, vinnuálag og streita fari vaxandi og starfið sé ekki eins eftirsóknarvert og áður var. Stéttin er að eldast og æ fleiri endast skemur í starfinu en æskilegt má telja.

Rannsóknir sýna að stuðningur í starfi getur gert gæefumuninn í pví hvernig einstaklingur tekst á við hlutverk sitt. Stuðningur getur verið margs konar, svo sem með ígrundun og lestri fræðilegs efnis, formlegu námi, námskeiðum og fræðslufundum ýmiss konar og heimsóknum í aðra skóla. Skólastjóri getur komið sér upp sérstökum bandamanni, leitað eftir stuðningi hjá samstarfsfélögum, nýtt sér óformlega eða formlega handleiðslu eða fengið stuðning hjá mentor. Engin heildstæð rannsókn er til á pví hvernig stuðningi skólastjóra í grunnskólum er háttað. Dví er áhugavert að kanna eðli og umfang pess stuðnings sem skólastjórar fá í starfi og pess stuðnings sem peir fengu við upphaf starfsferils síns. Eftirfarandi rannsóknarspurningar voru settar fram til að leiða rannsóknina: Hvaða stuðning fengu skólastjórar við upphaf starfsferils sins? Hvaða stuðning fá peir við núverandi aðstceður? Hver er pörf skólastjóra fyrir stuðning i starfi?

\section{Aðferð}

\section{Dátttakendur}

Pátttakendur í spurningakönnuninni voru allir grunnskólastjórar á landinu. Í Skólastjórafélagi Íslands voru um 550 félagsmenn og par af voru 174 skólastjórar haustið 2018. Samkvæmt vef Hagstofunnar voru árið 2018 72\% skólastjóra í grunnskólum konur og 28\% karlar (Hagstofa Íslands, 2019). Kynningarbréf og tengill á spurningalista voru send út af formanni Skólastjórafélags Íslands á póstlista félagsins fyrir hönd rannsakanda. Nánari upplýsingar um pátttakendur má sjá í töflu 1, en konur voru 68\% pátttakenda og 66\% pátttakenda stýrðu skóla utan höfuðborgarsvæðisins. 
Tafla 1. Pátttakendur og bakgrunnur peirra.

\begin{tabular}{|c|c|c|}
\hline & Hlutfall & Fjöldi` $(N)$ \\
\hline \multicolumn{3}{|l|}{$K y n$} \\
\hline Kona & $68 \%$ & 79 \\
\hline Karl & $32 \%$ & 37 \\
\hline \multicolumn{3}{|l|}{ Búseta } \\
\hline Höfuðborgarsvæðið & $34 \%$ & 39 \\
\hline Utan höfuðborgarsvæðisins & $66 \%$ & 75 \\
\hline \multicolumn{3}{|l|}{ Starfsreynsla sem skólastjóri } \\
\hline 0-3 ár & $34 \%$ & 39 \\
\hline 4-7 ár & $24 \%$ & 28 \\
\hline 8-11 ár & $14 \%$ & 16 \\
\hline 12 ár eða lengur & $28 \%$ & 33 \\
\hline \multicolumn{3}{|l|}{ Fjöldi starfsmanna } \\
\hline 30 eða færri starfsmenn & $34 \%$ & 40 \\
\hline 31 eða fleiri starfsmenn & $66 \%$ & 75 \\
\hline \multicolumn{3}{|l|}{ Noesti yfirmaður } \\
\hline Bæjar- eða sveitarstjóri & $34 \%$ & 40 \\
\hline Sviðsstjóri & $65 \%$ & 75 \\
\hline Annar aðili & $1 \%$ & 1 \\
\hline
\end{tabular}

$\star_{\mathrm{N}}=117$, mismunur felst í peim sem ekki svara.

\section{Spurningalisti}

Spurningalistanum var skipt upp í prjá hluta, sem voru: Bakgrunnsupplýsingar, stuðningur við upphaf starfs og stuðningur við núverandi aðstæður. Í fyrsta hluta könnunarinnar var spurt um bakgrunn pátttakenda, svo sem búsetu, reynslu í starfi, mannaforrád, kyn og hver væri næsti yfirmaður. Í öðrum hluta var spurt um pann stuðning sem skólastjóri fékk við upphaf ferils síns. Í priðja og síðasta hluta könnunarinnar var spurt um pann stuðning sem viðkomandi fær núna og pörf fyrir stuðning.

Degar skoðað var hvort marktækur munur kæmi fram eftir búsetu var notuð skipting á milli höfuðborgarsvæðis og landsbyggðarinnar. Á einum stað var pó eingöngu skoðað hvernig Reykjavík, ekki höfuðborgarsvæðið, kom út par sem mikill munur var á svörum peirra sem par störfuðu við spurningunni um hvort fræðslustjóri hefði komið á sambandi við reyndari skólastjóra. Pá var skólum einnig skipt upp í tvo flokka eftir fjölda starfsmanna, miðað var við 30 og færri starfsmenn og 31 og fleiri. Degar litið var til fjölda ára í starfi var pátttakendum skipt upp í tvo hópa, pá sem höfðu sjö ára og minni starfsreynslu og pá sem höfðu átta ára og meiri starfsreynslu. Dessi skipting var gerð til fá tvo hópa af sambærilegri stærð par sem annar var með frekar litla reynslu og hinn meiri.

Spurt var um á fimm punkta kvarða frá mjög sammála yfir í mjög ósammála hvort pörf pátttakenda fyrir stuðning í starfi væri fullnægt miðað við núverandi aðstæður. Nokkrar spurningar sneru að pví hvaðan og frá hverjum skólastjórar fengju stuðning í starfi eða hefðu fengið við upphaf ferlis. Í pessari spurningu var meðal annars spurt um stuðning frá maka, vinum, fræðsluyfirvöldum og Skólastjórafélaginu. Spurt var um stuðning við ákveðna pætti í skólastjórastarfinu, par á meðal erfið starfsmannamál, stefnumótun og faglega ráđgjöf. Svör voru á fimm punkta kvarða frá mjög miklum stuðningi yfir í engan eða mjög lítinn stuðning. Að lokum var spurt um pörf fyrir stuðning við pá pætti sem taldir höfðu verið upp. 
Spurningalistinn var forprófaður, en haft var samband við fjóra aðstoðarskólastjóra og peir beðnir að svara listanum og koma með ábendingar um óskýrt eða villandi orðalag spurninga eða svarmöguleika. Listinn var í framhaldinu endurbættur.

\section{Framkvæmd}

Skólastjórar fengu sendan tengil í desember 2018 ásamt kynningarbréfi. Áminning um pátttöku var send út viku eftir að upphaflega kynningarbréfið var sent og önnur ítrekun tæpum mánuði síðar. Đá minnti rannsakandi prisvar sinnum á könnunina í lokuðum Facebook-hópi skólastjórnenda. Könnuninni var lokað 25. janúar 2019.

Spurningalistinn var unninn í vefforritinu SurveyMonkey og öll svör skráðust par inn. Svör við spurningalistanum voru sett inn í Excel og SPSS-forritið. Reiknuð var lýsandi tölfræði og skoðað með kí-kvaðrat-prófi hvort marktækur munur væri á milli ákveðinna hópa. Skoðað var hvort marktækur munur kæmi fram eftir kyni, búsetu, hver næsti yfirmaður væri, starfsaldri og stærð skólans. Engin sérstök siðferðileg álitamál tengjast framkvæmd rannsóknarinnar; ekki var safnað viðkvæmum persónugreinanlegum upplýsingum og pátttakendur upplýstir um að peir mættu hafna pátttöku og sleppa einstökum spurningum.

\section{Niðurstöður}

\section{Stuðningur í starfi}

Ljóst er að pátttakendur töldu pað mikilvægt að fá stuðning í starfi. Aðspurðir sögðu 95\% skólastjóra að pað væri mjög eða frekar mikilvægt og enginn taldi að pað væri frekar eða mjög lítilvægt. Skólastjórarnir voru einnig spurðir hvort peir fengju pann stuðning sem peir teldu sig purfa í starfinu miðað við núverandi aðstæður og voru 47\% skólastjóra mjög eða frekar sammála pví að peir fengju pann stuðning sem peir pyrftu, en 28\% sögðust vera frekar eða mjög ósammála pví (sjá mynd 1). Engan marktækan mun var að finna á viðhorfum skólastjóra til pess hvort pörf fyrir stuðning væri fullnægt eftir kyni pátttakenda, búsetu, hvort yfirmaður væri bæjarstjóri eða sviðsstjóri, fjölda undirmanna eða starfsaldri.

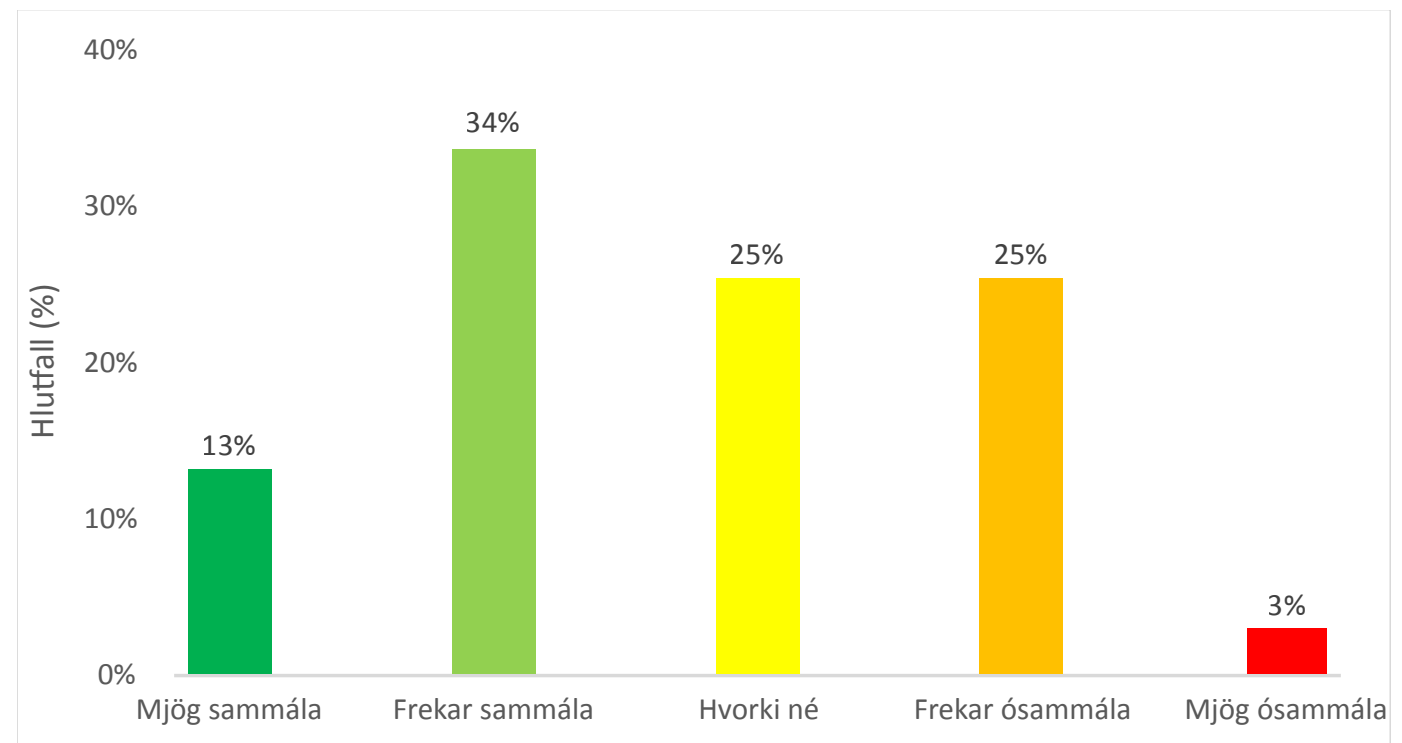

Mynd 1. Mat pátttakenda á pví hvort pörf fyrir stuðning væri fullnægt miðað við núverandi aðstæður. 
Dátttakendur voru inntir eftir pví hversu ánægðir eða óánægðir peir væru með pann stuðning sem peir hefðu fengið í upphafi skólastjóraferilsins og núna (sjá mynd 2). Í ljós kom að hlutfall skólastjóra sem voru mjög eða frekar ánægðir með pann stuðning sem peir fengu við upphaf ferils síns var aðeins $21 \%$, en 58\% voru frekar eða mjög óánægð með stuðninginn. Ánægja með stuðning núna var ívið meiri en við upphaf starfsferils, eins og sjá má á mynd 2. Priðjungur skólastjóra var mjög eða frekar ánægður með pann stuðning sem peir fengu núna. Enginn marktækur munur var á ánægju skólastjóra með stuðning við upphaf ferils og núna pegar litið var til bakgrunnsbreyta, pað er kyns, búsetu, næsta yfirmanns, fjölda starfsmanna og starfsreynslu.

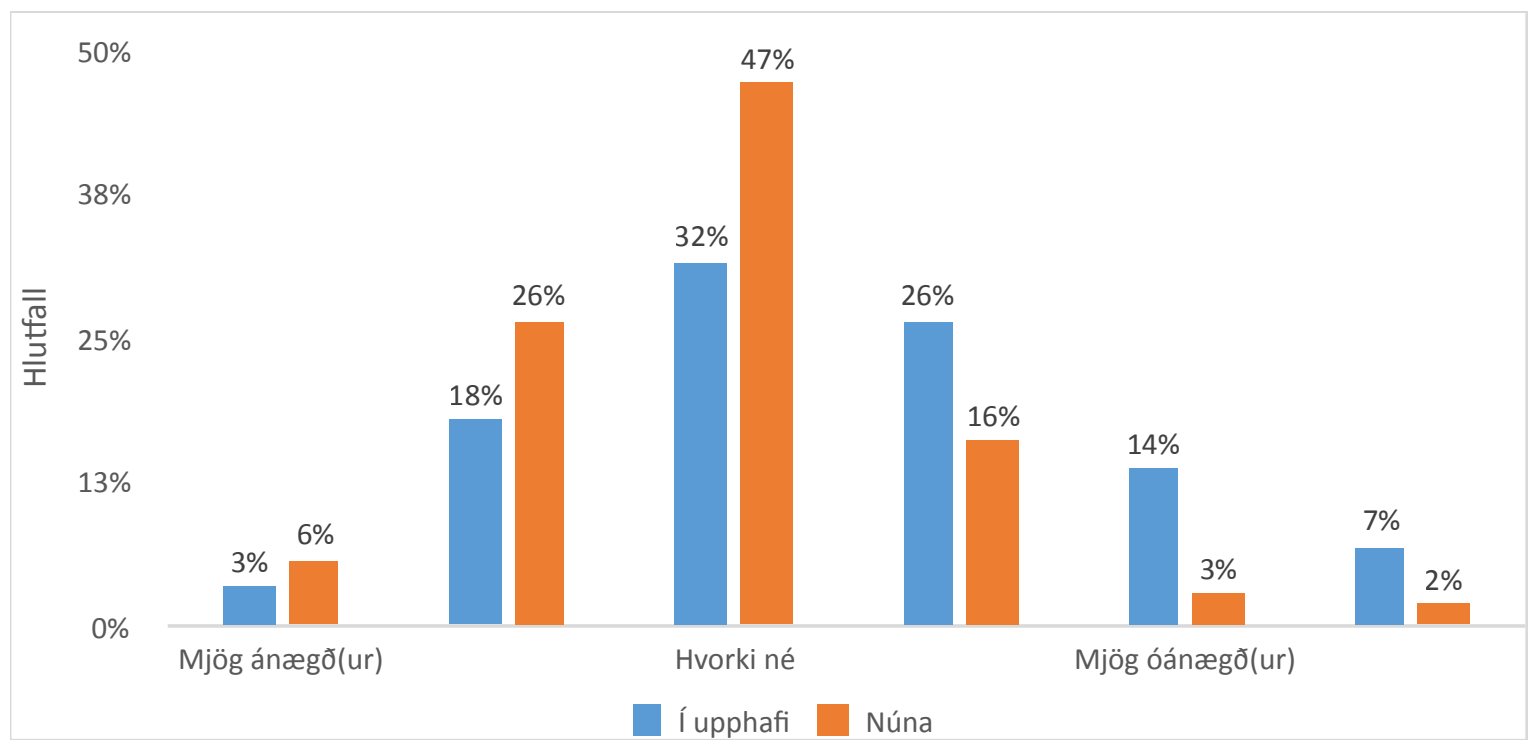

Mynd 2. Ánægja með stuðning við upphaf starfsferils og núna.

\section{Hvaðan kemur stuðningurinn?}

Nokkrar spurningar sneru að pví hvaðan skólastjórarnir fengju stuðning í starfi. Eins og sjá má á mynd 3 nefndu 70\% pátttakenda að við upphaf skólastjórastarfsins hefðu peir fengið mestan stuðning frá maka eða fjölskyldu og svipað hlutfall sagðist núna sækja pangað mikinn stuðning. Aðrir skólastjórar í sveitarfélaginu eða á svæðinu höfðu einnig veitt skólastjórum stuðning í upphafi, en 52\% sögðust hafa fengið mikinn eða mjög mikinn stuðning frá peim. Mikill stuðningur kom frá næsta undirmanni við núverandi aðstæður, en $72 \%$ nefndu pann aðila. Athygli vekur hversu fáir sögðust hafa fengið mikinn stuðning frá sérstökum handleiðara eða mentor, bæði í upphafi og núna. Dá virðist vera lítill stuðningur bæði við upphaf ferils og núna frá Skólastjórafélagi Íslands og fræðsluyfirvöldum í sveitarfélaginu, sjá nánar mynd 3. 


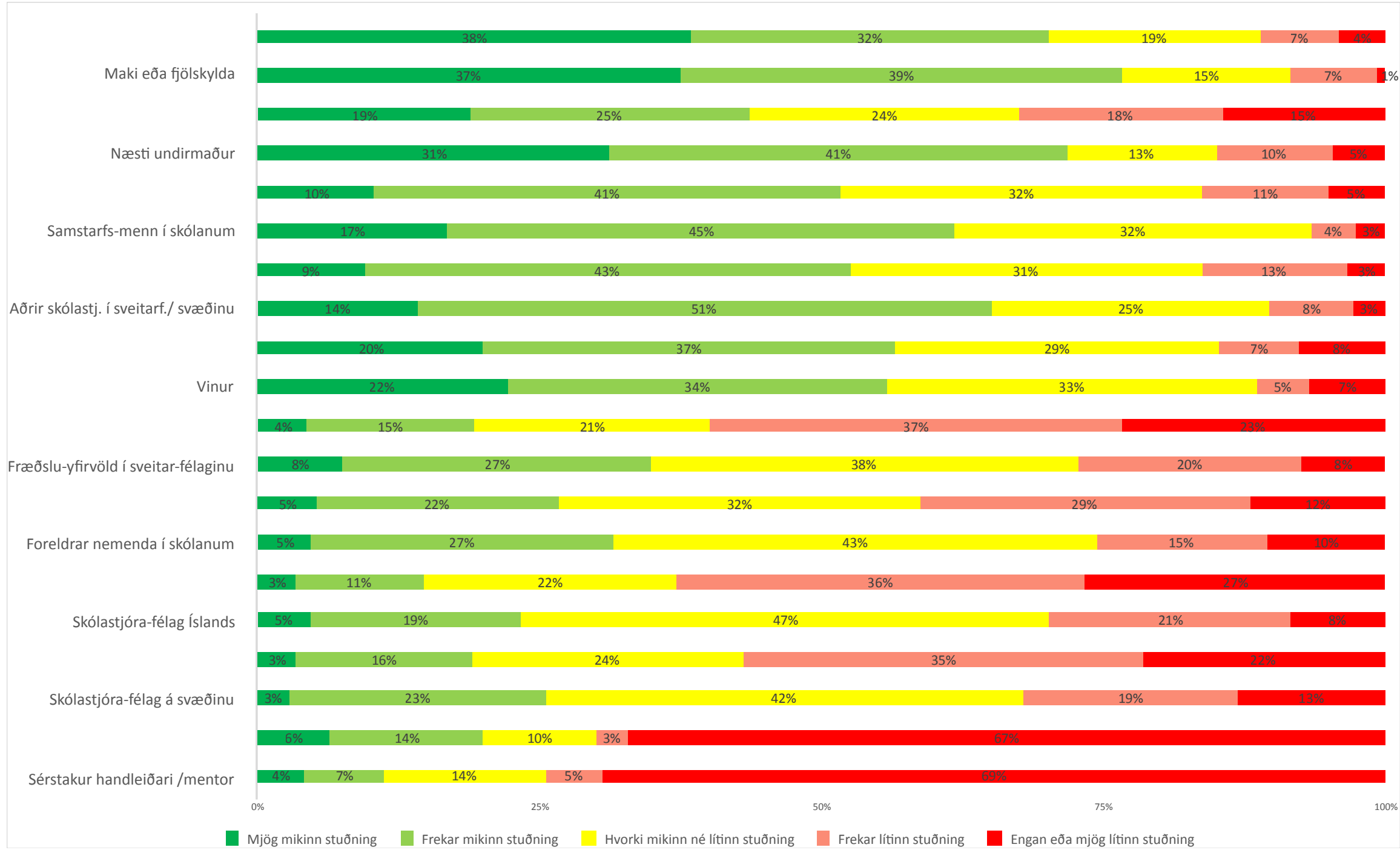

Mynd 3. Aðilar sem veita stuðning við upphaf skólastjóraferils og núna. 
Sérstaklega var litið til pess hvort munur væri á svörum skólastjóra með tilliti til yfirmanns pegar kæmi að stuðningi fræðsluyfirvalda. Deir sem höfðu sviðsstjóra sem næsta yfirmann en ekki bæjarstjóra voru líklegri til að svara að mikill stuðningur fengist frá fræðsluyfirvöldum núna. Pannig sögðu um $40 \%$ að frekar mikill eða mjög mikill stuðningur fengist frá fræðsluyfirvöldum, $\chi 2(2$, $\mathrm{N}=104)=10,2, \mathrm{p}=0,006$. Hlutfall skólastjóra sem sögðust hafa bæjarstjóra sem næsta yfirmann og fengu frekar eða mjög mikinn stuðning frá sveitarfélaginu var 18\%.

Ein leið til að veita nýjum skólastjórum stuðning er að koma á sambandi við reyndari skólastjóra. Degar spurt var hvort fræðsluyfirvöld hefðu komið slíku sambandi á svöruðu 79\% að svo hefði ekki verið en $21 \%$ að slíku sambandi hefði verið komið á. Skólastjórar í Reykjavík voru mun líklegri (75\%) en skólastjórar á landsbyggðinni (9\%) til að segja að slíku sambandi hefði verið komið á, $\chi 2(1, N=117)=43,9, p<0,001$. Marktækur munur kom einnig fram pegar skoðað var hver væri næsti yfirmaður $\chi 2(1, \mathrm{~N}=115)=9,4, \mathrm{p}<0,002$ og mannaforrád skólastjóra $\chi 2(1$, $\mathrm{N}=115)=6,6, p<0,01$. Um $29 \%$ peirra sem höfdu sviðsstjóra sem næsta yfirmann sögðu að svo hefði verið en 5\% peirra sem höfðu bæjarstjóra sem næsta yfirmann. Deir sem stýrðu stærri skólum svöruðu í 88\% tilfella að slíku sambandi hefði verið komið á en aðeins 13\% peirra sem stýrðu fámennari skólunum.

\section{Æskilegur stuðningur}

Á mynd 4 má sjá hvaða aðilar skólastjórar töldu að ættu að veita peim mestan stuðning. Langflestir, eða 69, settu fræðsluyfirvöld í fyrsta sæti yfir pá sem ættu að veita stuðning og flestir, eða 104, settu fræðsluyfirvöld í eitthvert af fimm efstu sætunum. Dar á eftir kom Skólastjórafélag Íslands, en 80 settu félagið í eitthvert af fimm efstu sætunum. Langfæstir settu maka eða fjölskyldu, foreldra í skólanum eða vini í eitthvert af fimm efstu sætunum. Dað er pví talsvert misræmi milli pess hvaðan skólastjórar fá stuðning og hvaðan peir telja að peir ættu að fá hann.

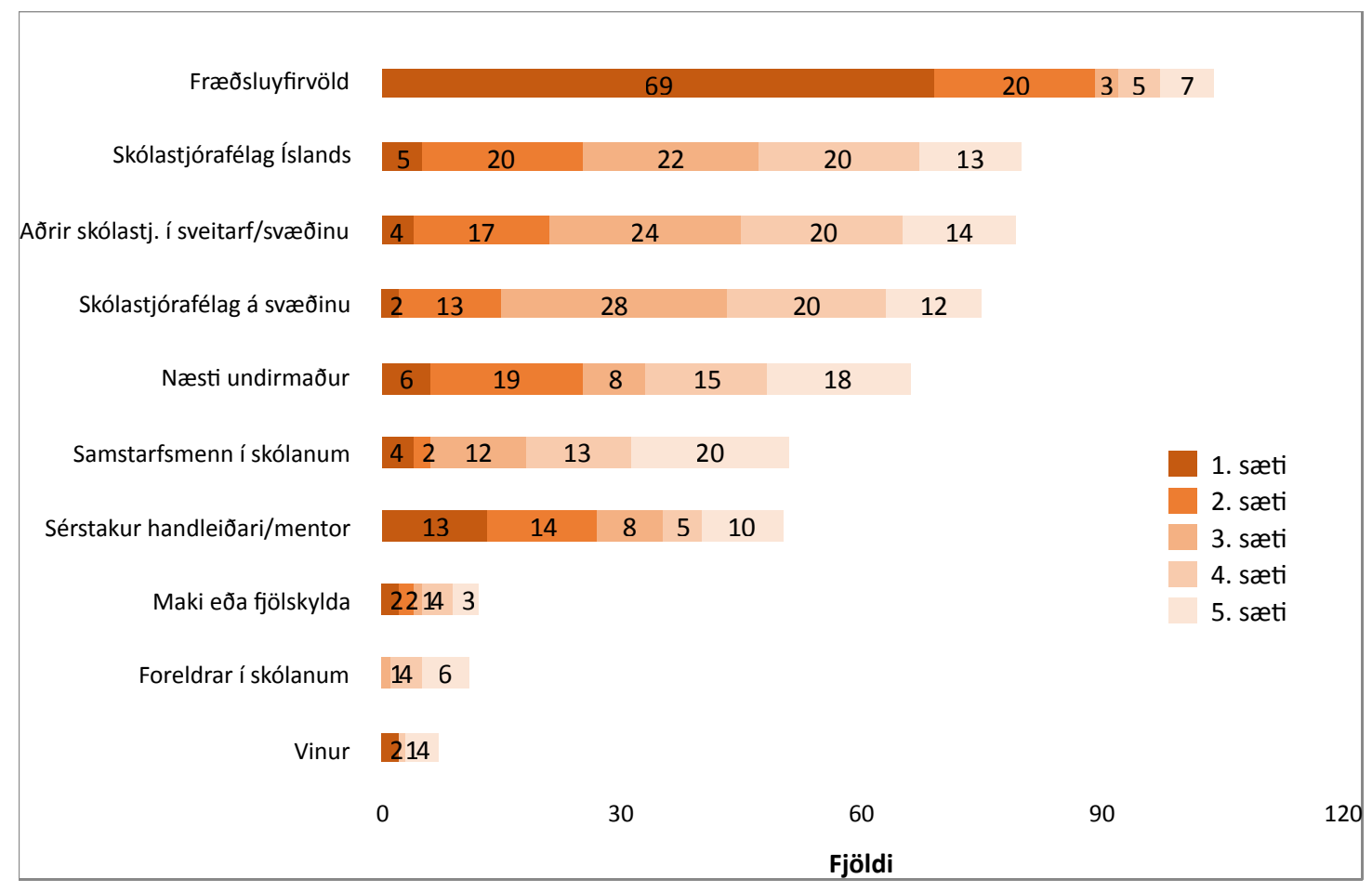

Mynd 4. Aðilar sem ættu helst að veita stuðning að mati skólastjóra. 
Pátttakendur í rannsókninni voru spurðir hversu mikinn eða lítinn stuðning peir fengju við ákveðna pætti starfsins, sjá mynd 5. Rétt um helmingur pátttakenda, eða 51\%, sagðist fá mjög mikinn eða frekar mikinn stuðning við erfið starfsmannamál og $48 \%$ við að leysa vandamál en aðeins $18 \%$ sögðust fá mjög eða frekar mikinn persónulegan stuðning.

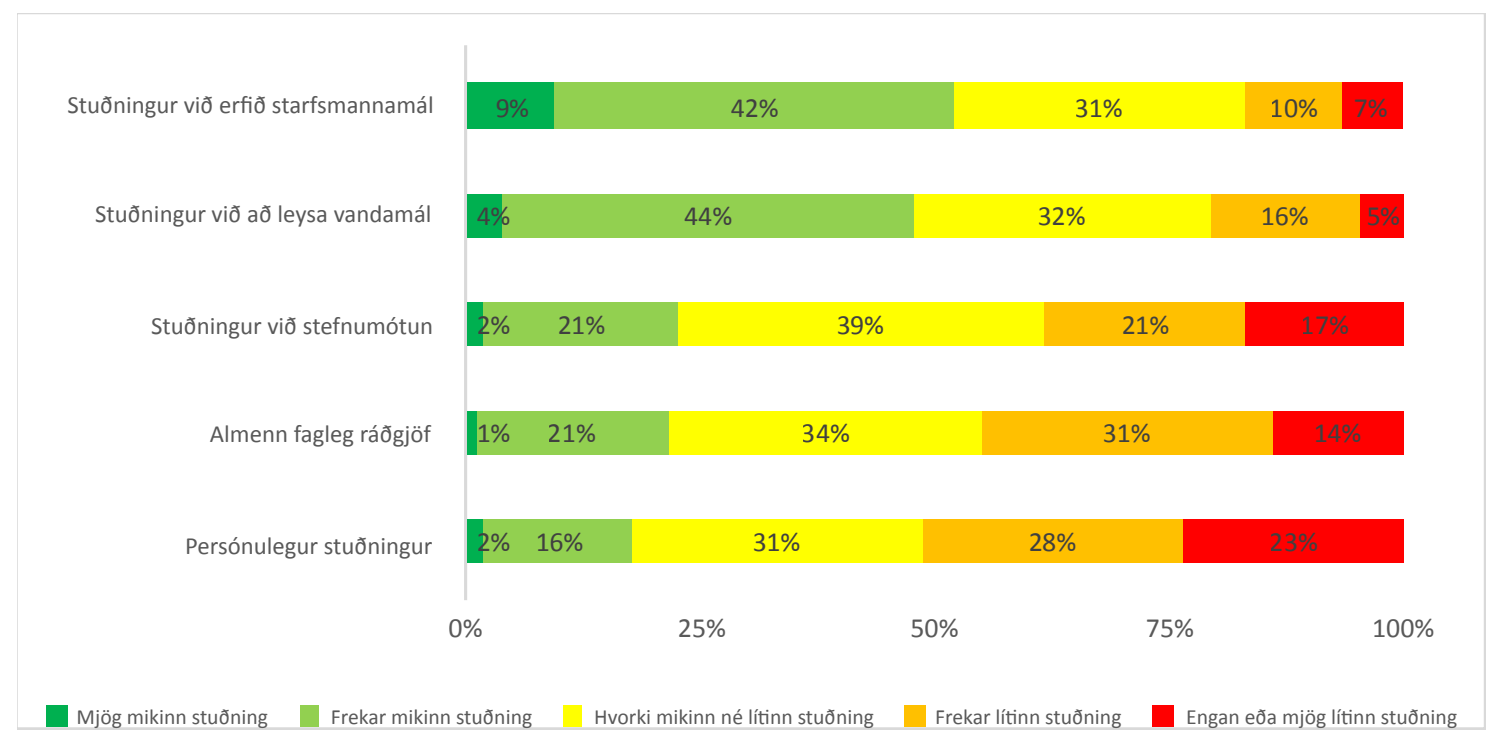

Mynd 5. Núverandi stuðningur við ákveðna pætti skólastjórastarfsins.

Svör pátttakenda um stuðning voru flokkuð í prjá flokka: Enginn, mjög eða frekar lítill stuðningur var einn flokkur, hvorki mikill né lítill stuðningur annar flokkur og frekar eða mjög mikill stuðningur priðji flokkurinn. Munur var á milli kynja pegar skoðað var hve mikinn stuðning skólastjórar fengu við að leysa erfið starfsmannamál, $\chi 2(2, \mathrm{~N}=105)=8,7, p=0,013$. Um 30\% karla og 9\% kvenna sögðust fá engan, mjög eða frekar lítinn stuðning við að leysa erfið starfsmannamál. Pá kom fram marktækur munur pegar litið var til stjórnunarreynslu og pess hve mikinn persónulegan stuðning skólastjórar fengu, $\chi 2(2, \mathrm{~N}=106)=6,7, p=0,035$. Af peim sem höfðu sjö ára starfsreynslu eða minna sögðu $40 \%$ að peir fengju hvorki mikinn né lítinn stuðning persónulega en $20 \%$ peirra sem höfðu starfað í átta ár eða lengur svöruðu eins. Deir sem höfu lengri starfsreynslu sögðu í 26\% tilfella að peir fengju mjög eða frekar mikinn stuðning persónulega en $12 \%$ peirra sem höfðu minni starfsreynslu. Ekki kom fram marktækur munur pegar niðurstöður voru skoðaðar með tilliti til búsetu, yfirmanns eða fjölda starfsmanna.

Degar aftur á móti var spurt hve mikinn eða lítinn stuðning við ákveðna pætti skólastjórarnir teldu sig purfa var niðurstaðan eins og sjá má á mynd 6. Hlutfall peirra sem sögðu sig purfa frekar eða mjög mikinn stuðning við erfið starfsmannamál var 50\% og 39\% töldu sig purfa frekar eða mjög mikinn stuðning við stefnumótun. Afar fáir, eða 7\%, töldu að peir pyrftu engan eða mjög lítinn stuðning við einhvern af peim páttum sem nefndir voru. 
Parfnast mjög mikils stuđ̃nings

parfnast ekki stuđ̃nings eđa mjög lítils stuđ̃ning

Mynd 6. Đörf fyrir stuðning við ákveðna pætti skólastjórastarfsins.

Pegar valmöguleikar höfðu verið flokkaðir saman í parfnast einskis, mjög lítils eða frekar lítils stuðnings, parfnast miðlungs stuðnings og parfnast frekar eða mjög mikils stuðnings kom í ljós marktækur munur á tveimur páttum. Munur var á milli hópa eftir búsetu, peir sem bjuggu á höfuðborgarsvæðinu og peir sem bjuggu utan pess töldu sig purfa mismikinn stuðning við að leysa vandamál, $\chi 2(2, \mathrm{~N}=105)=6,4, p=0,041$. Af skólastjórum á höfuðborgarsvæðinu sögðust $40 \%$ parfnast frekar eða mjög mikils stuðnings við að leysa vandamál en $27 \%$ peirra sem bjuggu á landsbyggðinni. Pá greindist einnig munur á peim skólastjórum sem voru með 30 eða færri undirmenn og peirra sem voru með fleiri pegar kom að аðstoð við stefnumótun, $\chi 2(2, \mathrm{~N}=105)$ $=6,4, p=0,041$. Deir skólastjórar sem stýrðu stærri skólum og voru með 31 eða fleiri starfsmenn sögðu í 20\% tilfella að peir pyrftu engan, frekar eða mjög lítinn stuðning við stefnumótun en 3\% peirra sem voru með 30 eða færri starfsmenn. Ekki var um annan marktækan mun að ræða pegar litið var til bakgrunnsbreyta.

\section{Umræða}

Spurningarnar sem lágu til grundvallar pessu rannsóknarverkefni snerust um stuðning við skólastjóra 1 starfi í upphafi ferils og við núverandi aðstæður auk pess að kanna hver pörfin væri fyrir stuðning að peirra mati. Баð er pví áhugavert að ræða um niðurstöður rannsóknarinnar á grundvelli peirra rannsóknarniðurstaða sem kynntar voru hér að framan.

\section{Stuðningur við upphaf starfsferils}

Stjórnunarreynsla um priðjungs skólastjóra sem svöruðu rannsókninni var prjú ár eða minna og um fjórðungur sagðist hafa fjögurra til sjö ára stjórnunarreynslu. Бað má pví gera ráð fyrir að mörgum svarendum sé fyrsta árið eða fyrstu árin í stjórnun enn í fersku minni. Рað að 58\% skólastjóra séu með sjö ára eða minni stjórnunarreynslu bendir til pess að stétt skólastjóra sé að yngjast og endurnýjast. Eins og kom fram í TALIS-könnuninni 2013 (OECD, 2014: Ragnar F. Ólafsson, 2014) voru 16\% skólastjóra yfir sextugu á Íslandi og pví líklegt að allmargir skólastjórar myndu á næstu fimm til sjö árum hætta störfum. Í TALIS-könnunin 2018 var meðalaldur skólastjóra svipaður og fimm árum fyrr sem bendir til að endurnýjun eigi sér stað í stéttinni (Ragnar F. Ólafsson, 2019).

Boerema (2011) bendir á að brýnt sé að skólastjórar fái góðan stuðning við upphaf ferils síns og að bæði purfi að styðja pá á formlegan og óformlegan hátt. Á Íslandi virðast skólastjórar hafa fengið 
meiri óformlegan stuðning við upphaf ferils síns en formlegan stuðning skipulagðan af utanaðkomandi aðilum. Hér er jafnan um óformlegan stuðning að ræða sem skólastjórar koma sér upp sjálfir. Sérstökum handleiðara eða mentor er ekki fyrir að fara, par sem 70\% skólastjóranna sögðu að enginn, mjög eða frekar lítill stuðningur hefði fengist frá slíkum aðila. Aðrir aðilar sem nefndir voru og höfðu veitt lítinn stuðning voru Skólastjórafélag Íslands og fræðsluyfirvöld.

Eins og kemur fram í skrifum Honig (2012) er mikilvægt að formlegur stuðningur komi frá fræðsluyfirvöldum og óeðlilegt er að leiðsögn eða stuðningur fáist fyrst og fremst frá samstarfsfélögum eða öðrum skólastjórnendum á svæðinu, sem pegar eru störfum hlaðnir. Баð er pví dapurlegt að sjá hve hátt hlutfall skólastjóra upplifði lítinn eða engan stuðning frá fræðsluyfirvöldum við upphaf ferils síns og vert að velta pví upp hvers vegna svo sé. Hluti af skýringunni gæeti verið einangrun skólastjóra. Oft er aðeins einn skóli í sveitarfélagi og pví ekki um eiginleg fræðsluyfirvöld að ræða. Næsti yfirmaður skólastjórans er pá bæjar- eða sveitarstjóri. Á peim stöðum par sem eru starfandi fræðsluskrifstofur gæti einnig verið viss fjarlægð milli fræðsluskrifstofa og skólastjóranna sem leiddi til pess að stuðningurinn yrði ekki eins og æskilegt mætti telja. Einnig er hugsanlegt að fræðsluskrifstofur purfi að sinna of mörgum skólum á stóru svæði.

Ein spurning í könnuninni var um hvort fræðsluyfirvöld hefðu komið á sambandi við reyndari skólastjóra í sveitarfélaginu. Yfirleitt reyndist svo ekki vera en eitt sveitarfélag skar sig úr í pessum efnum. Skólastjórar í Reykjavík voru mun líklegri en aðrir til að svara pessari spurningu játandi. Fleiri sveitarfélög mættu koma upp svipuðu verklagi og Reykjavík og bjóða nýjum skólastjórum handleiðslu hjá reyndari skólastjóra, sérstökum handleiðara eða mentor. Slíkt myndi nýtast vel fyrsta árið og jafnvel lengur, eins og Aguilar og félagar (2011) benda á. Í flóknu starfsumhverfi skólastjórans gæeti líka verið gott að koma sér upp sérstökum bandamanni eða að slíku fyrirkomulagi yrði til dæmis komið á á vettvangi Skólastjórafélags Íslands. Sú leið að skapa grundvöll fyrir tvo eða fleiri skólastjóra til að tengjast gæti reynst peim vel. Pannig gætu peir farið saman í gegnum fyrstu starfsárin, deilt reynslu sinni og miðlað pekkingu.

Degar spurt var um ánægju skólastjóra með stuðning við upphaf ferils síns var hlutfall peirra sem voru frekar eða mjög ánægðir með pann stuðning sem peir fengu aðeins 21\% en 58\% voru frekar eða mjög óánægðir. Dessar niðurstöður eru í samræmi við pað sem Gerður Ólína Steinpórsdóttir (2014) komst að í sinni rannsókn, par sem 70\% grunnskólastjóra sögðust sjaldan eða aldrei hafa fengið stuðning fyrsta starfsárið sitt.

Eins og Lee (2015) bendir á, pá parf að undirbúa skólastjóraskipti á faglegan hátt. Skólastjóri parf аð vita að hann fái pann stuðning sem hann parf, vita eftir hverju á að leita og hvert á að sækja stuðninginn. Баð að skólastjóri fái að fylgja fráfarandi skólastjóra, honum sé útvegaður handleiðari og að fræðsluyfirvöld veiti örugglega upplýsingar um pann stuðning sem er í boði skiptir meginmáli að mati Lee (2015). Sú staðreynd að aðeins um fimmtungur skólastjóra hér á landi sé ánægður með pann stuðning sem fékkst við upphaf starfsferils sýnir að ekki hefur verið nægjanlega hugað að stuðningi við nýja skólastjóra.

\section{Stuð̃ningur í starfi vio núverandi aðstæour}

Degar kom að spurningum um stuðning í starfi við núverandi aðstæður má sjá að ánægja með núverandi stuðning var aðeins meiri en var við upphaf ferils. Hlutfall skólastjóra sem sögðust vera mjög eða frekar ánægðir með núverandi stuðning í starfi var rétt tæplega priðjungur, en var 21\% í upphafi. Hlutfall skólastjóra sem voru frekar eða mjög óánægðir með núverandi stuðning var 19\%. Næstum allir skólastjórar sem tóku pátt í könnuninni, 95\%, voru sammála um að stuðningur við pá væri frekar eða mjög mikilvægur.

Eins og fram hefur komið hefur starfsumhverfi skólastjóra breyst gríðarlega mikið á síðustu 20 árum (Anna María Skúladóttir, 2015; Börkur Hansen o.fl., 2008). Kröfur til stjórnenda hafa aukist og samfara pví hafa skólastjórar greint frá aukinni streitu (Education Support Partnership, 
2017; Gerður Ólína Steinpórsdóttir, 2014). Í ljósi pess kalla skólastjórar eftir meiri stuðningi, sem er eðlilegt. Rannsóknir í Kanada sýna að skólastjórar par kalla eftir auknum stuðningi við störf sín, meðal annars vegna breytinga í starfsumhverfinu (Canadian Association of Principals og The Alberta Teachers' Association, 2014). Dað er líklegt að skólastjórar á Íslandi standi í svipuðum sporum og skólastjórar í Kanada og purfi aukinn stuðning í pví flókna starfsumhverfi sem hér hefur bróast. Af pessu má draga pá ályktun að pó að um helmingur skólastjóra fái frekar eða mjög mikinn stuðning í starfi, pá sé pörf á enn markvissari og öflugri stuðningi en er í boði til að mæta peim breytingum sem hafa orðið í starfsumhverfi peirra.

Раð er áhyggjuefni að aðeins priðjungur skólastjóra skuli vera ánægður með pann stuðning sem peir fá nú. Pessar niðurstöður eru sterk vísbending um að allir hagsmunaaðilar purfi að taka höndum saman og huga sérstaklega að pessum pætti. Skólastjórar purfa að gera sér grein fyrir pví hvaða stuðning vantar, óska eftir honum og prýsta á að stuðningur sé ávallt í boði. Fræðsluyfirvöld og aðrir hagsmunaaðilar purfa að skilgreina betur hlutverk sitt og skipuleggja formlegan og markvissan stuðning við stjórnendur. Ef slíkt væri gert er líklegra að starfsánægja skólastjóra myndi aukast, starfið yrði eftirsóknarverðara og umsóknum um stöður skólastjóra myndi fjölga. Einnig má telja líklegt að fleiri hefðu pá áhuga á að mennta sig í stjórnun menntastofnana, og pað stuðlaði síðan að pví að efla stéttina sem slíka.

Degar niðurstöður um stuðning við upphaf ferils og niðurstöður er varða núverandi stuðning eru skoðaðar kemur í ljós að óformlegur stuðningur er sá stuðningur sem skólastjórar helst fá og reiða sig mest á. Fyrir utan pað að nefna fjölskyldu og maka sem helstu stuðningsaðila segjast peir einnig fá frekar eða mjög mikinn stuðning frá vini og öđrum skólastjórum í sveitarfélaginu eða á svæðinu. Hlutfall peirra sem nefna fjölskyldu og maka sem pann aðila sem veitir frekar eða mjög mikinn stuðning er 76\% og hefur hækkað um sex prósentustig frá upphafi ferils. Par á eftir kemur аð næsti undirmaður veiti mjög eða frekar mikinn stuðning og síðan samstarfsmenn í skólanum. Skólastjórar virðast pví treysta mjög á stuðning frá fjölskyldu og maka og næsta undirmanni. Telja má óeðlilegt að bæði við upphaf ferils og nú séu helstu stuðningsaðilar skólastjóra fjölskylda og maki. Auðvitað er eðlilegt að slíkir aðilar styðji við bakið á skólastjóranum en mesti stuðningurinn ætti pó að vera frá öðrum aðilum og vera formlegri.

Í rannsókninni kom fram munur á milli hópa eftir pví hver var næsti yfirmaður. Deir sem höfðu sviðsstjóra eða deildarstjóra sem næsta yfirmann voru líklegri til að segja að frekar eða mjög mikill stuðningur fengist frá slíkum aðila. Deir skólastjórar sem stýra skólum í sveitarfélögum par sem ekki er fræðslustjóri eiga greinilega ekki sama kost á stuðningi frá fræðsluyfirvöldum pegar næsti yfirmaður peirra er bæjarstjóri. Detta má líta á sem vísbendingar um aðstöðumun skólastjóra eftir gerð og stærð sveitarfélaga. Баð má leiða að pví líkum að bæjar- eða sveitarstjóri sé fjarlægari og verr til pess fallinn að veita skólastjóra á staðnum almenna faglega ráđgjöf eða persónulegan stuðning, enda í mörg horn að líta hjá bæjarstjóra. Auk pess er ólíklegt að peir aðilar sem ráđast til slíkra starfa hafi faglega pekkingu á skólastjórastarfinu. Dá er mikilvægt, eins og Mendels (2017) bendir á, að fræðsluyfirvöld séu ekki í eftirlitshlutverki heldur veiti skólunum markvissan og öflugan stuðning.

Niðurstöður benda til pess að skólastjórar upplifi lítinn sem engan stuðning frá stéttarfélagi sínu og svæðafélögum stjórnenda, en benda má á að félög skólastjóra hafa verið ötul við bjóða upp á ráđstefnur, fundi og námskeið til að styðja félaga sína (Dorsteinn Sæberg, munnleg heimild, 25. október 2018). Í ljósi pess að pessir aðilar raðast í neðstu sætin yfir pá aðila sem skólastjórar telja að veiti frekar eða mjög mikinn stuðning, en peir kalla mjög eftir að peir veiti stuðning, er brýnt аð félagið skoði hvað er hægt að gera betur. Gott dæmi um öflugan stuðning frá kennara- og skólastjórasamtökum má sjá pegar litið er til Kanada. Skólastjórafélag Íslands er nú pegar komið í samstarf við Kanada um gagnkvæmar heimsóknir skólastjóra og pví eru hæg heimatökin að afla upplýsinga og gagna um pað hvernig stuðningi við skólastjóra er háttað par (Skólastjóraskipti Ísland - Canada, 2018). Darna eru tækifæri fyrir félagið til að láta meira til sín taka og vera leiðandi í pví að veita skólastjórum stuðning. 
Skólastjórafélag Íslands gæti einnig lagt til við næstu kjarasamninga skólastjórnenda að handleiðsla yrði eitt af pví sem stjórnendur ættu rétt á, sveitarfélög ættu að útvega og greiða fyrir. Баð er brýnt að slíkur stuðningur sé fyrir hendi en sé ekki eingöngu í boði pegar áföll eða erfiðleikar skjóta upp kollinum. Eins og Whitmore (2017) bendir á, pá hámarkar handleiðsla mögulega hæfni pess sem hennar nýtur. Баð að geta rætt starf sitt við aðila sem ekki er tengdur skólastjóranum, aðila sem aðstoðar skólastjórann við að finna lausn á vandamálinu og hlustar án pess að axla ábyrgð, skiptir miklu máli og er mikilvæg leið fyrir skólastjóra til að ráða betur við starf sitt.

\section{Stuðningsaðilar og pörf fyrir stuðning}

Degar skólastjórar voru beðnir að raða í sæti peim sem ættu að veita mestan stuðning birtist mynd sem er nokkuð fjarri pví hvernig peir lýstu raunverulegum stuðningi. Langflestir settu fræðsluyfirvöld í eitt af fimm efstu sætunum. Skólastjórafélag Íslands, aðrir skólastjórar á svæðinu og svæðafélög skólastjórnenda komu par á eftir. Niðurstöðurnar leiddu í ljós að fjölskylda og maki veittu hvað mestan stuðning en pátttakendur töldu að petta ættu ekki að vera helstu stuðningsaðilarnir. Samkvæmt pví sem skólastjórar sögðu nýttu peir sér að mestu óformlegan stuðning en kölluðu helst eftir formlegum, skipulegum stuðningi annarra aðila, eins og fræðsluyfirvalda.

Раð að skólastjórar leita til fjölskyldu og vina sem helsta stuðningsaðila má hugsanlega rekja til einangrunar í starfi. Boerema (2011) og Bauer og Silver (2018) benda á að skólastjórar upplifi sig einangraða í starfi og mikilvægt sé að rjúfa pá einangrun með markvissum hætti. Dað er meðal annars hlutverk fræðsluyfirvalda. Hlutverk fræðsluskrifstofu er bví ekki eingöngu falið í bví að veita faglegan stuðning heldur einnig að koma til dæmis á eða bjóða skólastjórum upp á formlega handleiðslu utanaðkomandi aðila, svo sem sálfræðinga eða sérfræðinga í stjórnun. Stuðningur fræðsluyfirvalda er einnig mikilvægur til að umbætur í skólastarfi eigi sér stað, eins og Honig (2012) bendir á. Fræðsluyfirvöld ættu jafnvel einnig að íhuga, í samráði við Skólastjórafélag Íslands, að gefa út einhvers konar viðmið um störf skólastjóra, eins og pekkist víða annars staðar í heiminum (Alberta Government, 2018; Australian Institute for Teaching and School Leadership, 2011; National Policy Board for Educational Administration, 2015). Slík viðmið gæfu vísbendingar um hvernig skólastjóri ætti að starfa og gætu nýst peim við að meta störf sín.

Pegar skólastjórar voru spurðir hve mikinn stuðning peir fengju við ákveðna pætti starfsins kom í ljós að mjög lágt hlutfall peirra fékk mjög mikinn stuðning við eitthvert af peim verkefnum sem spurt var um. Hlutfall peirra sem sögðust fá mjög mikinn stuðning fór aldrei yfir $9 \%$. Mestan stuðning fengu skólastjórar við úrvinnslu erfiðra starfsmannamála og við að leysa vandamál tengd skólastarfinu. Mest var um miðlungsstuðning við stefnumótun og minnst var um almenna faglega ráđgjöf og persónulegan stuðning. Karlmenn voru líklegri en konur til að nefna að peir fengju engan, mjög eða frekar lítinn stuðning við að leysa erfið starfsmannamál og peir sem höfðu lengri starfsreynslu voru líklegri til að segja að peir fengju mjög eða frekan mikinn persónulegan stuðning en peir sem höfðu sjö ára starfsreynslu eða minna. Hér mætti draga pá ályktun að með hærri starfsaldri hafi skólastjórar myndað sterkari tengsl við nærumhverfið og pví auðsóttara fyrir pá að fá stuðning.

Pörf skólastjóra á stuðningi við mismunandi pætti starfsins er áhugaverð. Hlutfall peirra sem töldu sig purfa frekar eða mjög mikinn stuðning við stefnumótun og persónulegan stuðning var hærra en peir sögðu að peir fengju. Hlutfall peirra sem svöruðu að peir pyrftu engan eða mjög lítinn stuðning við ákveðna pætti starfsins var einnig mjög lágt. Enginn skólastjóri taldi sig purfa engan eða mjög lítinn stuðning við úrlausn erfiðra starfsmannamála eða við stefnumótun. Örfáir sögðust ekki purfa stuðning við að leysa vandamál eða stuðning við sig persónulega. Dað má pví ætla, út frá niðurstöðunum, að skólastjórar telji sig purfa nokkuð mikinn stuðning við flest pau mál sem peir glíma við.

Degar skólastjórar á landsbyggðinni voru bornir saman við skólastjóra á höfuðborgarsvæðinu kom í ljós að hlutfall peirra sem sögðust purfa frekar eða mjög mikinn stuðning við að leysa vandamál 
var talsvert hærra hjá peim sem búa í höfuðborginni. Skólastjórar á landsbyggðinni sögðu frekar að peir pörfnuðust einskis, mjög eða frekar lítils stuðnings við að leysa vandamál. Баð má velta fyrir sér hvort vandamálin sem skólastjórar í höfuðborginni glíma við séu flóknari á einhvern hátt og peir purfi pví meiri stuðning við að leysa pau en skólastjórar á landsbyggðinni.

Marktækur munur kom einnig í ljós pegar litið var til fjölda starfsmanna í skólanum og stuðnings við stefnumótun. Skólastjórar í stærri skólum, með 31 starfsmann eða fleiri, sögðu frekar að peir pörfnuðust einskis, mjög eða frekar lítils stuðnings við stefnumótum. Detta gæti stafað af pví að í stærri skólum eru fleiri aðilar við stjórnun en í minni skólum. Stjórnendur í peim stærri skiptu með sér verkum og mótuðu stefnu skólans með starfsmönnunum. Skólastjórar í litlum skólum með 30 eða færri starfsmenn gætu upplifað sig undirmannaða til að takast á við stefnumótunina og pví purft meiri stuðning við pað en kollegar peirra í stærri skólum.

Skólastjórar á Íslandi virðast vera mjög virkir í að sækja pá endurmenntun, starfspróun og ráðstefnur sem í boði eru, eins og kemur fram í niðurstöðum rannsóknarinnar. Ef horft er á formlega háskólamenntun pá eru um 55\% skólastjóra og 26\% kennara á unglingastigi með meistarapróf (Ragnar F. Ólafsson, 2019). Skólastjórar sem hafa sviðsstjóra sem næsta yfirmann eru líklegri til að segjast vera virkir í starfspróun, svo og peir sem stýra stærri skólum. Pá er hægt að leiða að pví líkum að peir sem stýra stærri skólum hafi fleiri meðstjórnendur, dreifð forysta sé við lýði og pví sé auðveldara fyrir stjórnendur að yfirgefa vinnustaðinn og sinna starfspróun á vinnutíma, eins og Harris (2003) bendir á.

„Einginn er einn pó hann virðist stakur“ orti Porsteinn frá Hamri og vel mætti heimfæra pað á skólastjóra í grunnskólum landsins. Deir virðast margir hverjir vera einir á báti með alla præði starfsins í höndum sér en víða má finna og fá stuðning ef eftir honum er leitað. Dað er von höfunda að stuðningur við skólastjóra eigi eftir að eflast og styrkjast.

\section{Support for Principals in Compulsory Schools in Iceland - What They Get and What They Wish For}

The conditions in which principals work have changed drastically over the past decades. Many aspects of the principal's role have become more complex, and the demands of the job continue to escalate. These changes, in addition to causing a heavier workload, have increased the need for support for both new and experienced principals. The main purpose of this research project was to study the support that compulsory school principals in Iceland received when they first started their careers, the kind of support they now receive, and their perceived needs for support on the job. Furthermore, principals were asked from what source most of the support should come.

Constructive support is vital to principals, both in the early stages as well as later in their career. Boerema (2011) asserts that constructive support for school principals should be provided both in the beginning and throughout their career. He states that it is becoming more common for principals to quit their jobs or change careers after a few years. Evans (2010), Hargreaves and Fink (2006), and Meyer, Macmillan and Northfield (2011) share this observation and point out that frequent changes of principals can have negative effects on school staff, stability in school operations, and student achievement. In the same way, Honig (2012) states that constructive support of school principals can facilitate better leadership practices and improve schooling. 
Support to school principals can be provided in various ways. Preparation and support are quite strategic in some countries, while not in others (Pont, Nusche og Moorman, 2008). According to Lee (2015), the support can range from assisting new principals with practical matters concerning the management and operation of schools to personal support and development on the job. Whitmore (2017) outlines several forms of coaching as types of support, ranging from formal to informal. According to Retelle (2010), mentoring and coaching are support schemes of a similar nature that emphasise context-based learning. In some instances, the focus can be on developing competencies for dealing with difficult staff issues, while in other cases, the emphasis can be on personal growth and development in general. Pardini (2000) and Marsh (2010) claim that the main purpose of all available support schemes for school principals is to assist them, in one way or another, in fulfilling their role as school leaders as effectively possible.

In Iceland, no quantitative study has yet been conducted regarding what principals think about the support they get and what kind of support they need and prefer. This study provides new information, understanding, and knowledge about support of principals in Iceland. This knowledge and understanding can be utilized by education district offices, the Union of Principals, and the principals themselves for policy making and actions regarding provisions for support.

A questionnaire was developed to collect the necessary data. It was sent to all compulsory school principals in Iceland, 174 in total, and the response rate was $67 \%$. The survey was conducted using SurveyMonkey software, and the findings were analysed in Excel and SPSS.

The main findings of the study show that the majority of the principals are rather dissatisfied with the support they received in their beginning years as principals, and only $32 \%$ are content with their current level of support. Most of the principals reported that their main support came from family members or friends, both in the beginning of their career and now. Nearly all the principals, 95\%, agreed on the importance of receiving support in their role as principals. In addition, they maintained that this should primarily be provided by educational district offices. The study also revealed that the kind of support principals need most is related to managing difficult staff problems and policy making.

The response rate in this study was acceptable. The distribution of answers from different parts of the country reflect the actual numbers in each area. Therefore, the findings can be seen as providing useful insights regarding the support Icelandic compulsory principals in general receive and the support they need. Key support providers, such as educational district offices and the Union of Principals, can utilize these findings to develop and further enhance support for principals in all parts of the country.

Keywords: Principals, compulsory schools, support at the beginning of the careers, need for support, current support on the job 


\section{Um höfundana}

Sigurbjörg Róbertsdóttir (sigrob@simnet.is) er skólastjóri i Akurskóla í Reykjanesbæ og hefur verið pað síðan 2012. Sigurbjörg starfaði áður sem umsjónarkennari í Njarðvíkurskóla í 10 ár og sem deildarstjóri í Heiðarskóla í 9 ár. Hún lauk B.Ed.-prófi frá Kennaraháskóla Íslands árið 1993 og meistaraprófi í stjórnun menntastofnana frá Háskóla Íslands vorið 2019. Rannsóknin sem pessi grein byggist á var hluti af meistararitgerð hennar.

Amalía Björnsdóttir (amaliabj@hi.is) er prófessor við Deild heilsueflingar, íprótta og tómstunda á Menntavísindasviði Háskóla Íslands. Hún lauk B.A.-prófi í sálfrææi frá Háskóla Íslands árið 1991, M.Sc.-prófi frá háskólanum í Oklahoma 1994 og doktorsprófi frá sama skóla 1996. Hún hefur lagt stund á rannsóknir á sviði mælinga og prófagerðar, lestrar- og málproskamælinga, skólastjórnunar og áhrifa félagslegra pátta á skólastarf.

Börkur Hansen (borkur@hi.is) er prófessor við Deild kennslu- og menntunarfræði á Menntavísindasviði Háskóla Íslands. Hann lauk B.A.-prófi í uppeldis- og sálfræði frá Háskóla Íslands árið 1982, M.Ed.-prófi í menntastjórnun frá Háskólanum í Alberta árið 1984 og doktorsprófi frá sama skóla árið 1987. Rannsóknir hans hafa einkum beinst að skólastjórnun, forystu, skólapróun og stjórnskipulagi skóla.

\section{About the authors}

Sigurbjörg Róbertsdóttir (sigrob@simnet.is) has been principal in Akurskóli in Reykjanesbær since 2012. Previously she worked as a teacher in Njarðvíkurskóli, for 10 years, and as a head of department in Heiðarskóli for 9 years. She completed a B.Ed. degree in education from the Iceland University of Education in 1993 and an M.Ed. in educational administration from the University of Iceland in 2019. This paper is based on her master's thesis.

Amalía Björnsdóttir (amaliabj@hi.is) is a professor at the School of Education, University of Iceland. She completed a B.A. degree in psychology from the University of Iceland in 1991, and a Ph.D. from the University of Oklahoma in 1996. Her major research interests are in the areas of measurement and testing (reading and language development), school management and impacts of social factors on education.

Börkur Hansen (borkur@hi.is) is a professor at the School of Education, University of Iceland. He completed a B.A. in education and psychology from the University of Iceland in 1982, an M.Ed. in educational administration from the University of Alberta in 1984 and a Ph.D. in 1987. His major research interests are in the areas of leadership, school management, school development and educational governance. 


\section{Heimildir}

Aguilar, E., Goldwasser, D. og Tank-Crestetto, K. (2011). Support principals, transform schools: Even a great school leader needs a coach. Educational Leadership, 69(2), 70-73.

Alberta Government. (2018). Alberta education: Leadership quality standard. Sótt af https://education.alberta. ca/media/3739621/standardsdoc-lqs-_fa-web-2018-01-17.pdf

The Alberta Teachers'Association. (2018, desember). Publications. Sótt af https://www.teachers.ab.ca/News\%20 Room/Publications/Pages/Publications.aspx

Anna María Skúladóttir. (2015). Himinn og haf: Breytingar á starfi skólastjóra á 20 ára tímabili (oútgefin meistararitgerð). Sótt af http://hdl.handle.net/1946/20670

Australian Institute for Teaching and School Leadership. (2011). Australian professional standard for principals and the leadership profiles. Sótt af https://www.aitsl.edu.au/docs/default-source/default-document-library/australian-professional-standard-for-principals-and-the-leadership-profiles652c8891b1e86477b58fff00006709da. pdf?sfvrsn=11c4ec3c_2

Bauer, S. C. og Silver, L. (2018). The impact of job isolation on new principals' sense of efficacy, job satisfaction, burnout and persistence. Journal of Educational Administration, 56(3), 315-331. doi:10.1108/JEA07-2017-0078

Birna Sigurjónsdóttir og Börkur Hansen. (2014). Gildi og áherslur skólastjóra í grunnskólum í Reykjavík. Netla - Veftímarit um uppeldi og menntun. Sótt af http://netla.hi.is/greinar/2014/ryn/001.pdf

Boerema, A. J. (2011). Challenging and supporting new leader development. Educational Management Administration E Leadership, 39(5), 554-567. doi:10.1177/1741143211408451

Bush, T. (2018). Preparation and induction for school principals: Global perspectives. Management in Education, 32(2), 66-71. doi:10.1177/0892020618761805

Börkur Hansen, Ólafur H. Jóhannsson og Steinunn Helga Lárusdóttir. (2008). Breytingar á hlutverki skólastjóra í grunnskólum - kröfur, mótsagnir og togstreita. Uppeldi og menntun, 17(2), 87-104. Sótt af https:// timarit.is/view_page_init.jsp?pageId=5016556\&issId=323318\&lang=da

Börkur Hansen og Steinunn Helga Lárusdóttir. (2014). Stjórnun og skipulag. Í Gerður G. Óskarsdóttir (ritstjóri), Starfshœettir í grunnskólum við upphaf 21. aldar (bls. 87-112). Reykjavík: Háskólaútgáfan.

Canadian Association of Principals og The Alberta Teachers' Association. (2014). The future of the principalship in Canada: A national research study. Sótt af https://www.teachers.ab.ca/SiteCollectionDocuments/ATA/ Publications/Research/The\%20Future\%20of\%20the\%20Principalship\%20in\%20Canada.pdf

Daresh, J. (2004). Mentoring school leaders: Professional promise or predictable problems? Educational Administration Quarterly, 40(4), 495-517. doi:10.1177/0013161X04267114

Education Support Partnership. (2017). Health survey 2017: The mental health and wellbeing of education professionals in the UK. Sótt af https://www.educationsupportpartnership.org.uk/sites/default/files/education_staff_health_survey_2017.pdf

Evans, R. (2010). Seven secrets of the savvy school leader: A guide to surviving and thriving. San Francisco:Jossey-Bass.

Fink, D. og Brayman, C. (2004). Principals' succession and educational change. Journal of Educational Administration, 42(4), 431-449. Sótt af https://search.proquest.com/docview/220460833?accountid=135943

Fjórir skólastjórar ráđnir í Reykjavík. (2015, 16. apríl). Mbl.is. Sótt af https://www.mbl.is/frettir/innlent/2015/04/16/fjorir_skolastjorar_radnir_i_reykjavik/

Fullan, M. (2014). The principal: Three keys to maximizing impact. San Francisco: Jossey-Bass.

Gerður Ólína Steinpórsdóttir. (2014). Er kertið pitt að brenna út skólastjóri?: Kulnun grunn- og leikskólastjóra (óútgefin meistararitgerð). Sótt af http://hdl.handle.net/1946/19482

Hagstofa Íslands. (2019, nóvember). Starfsfólk í grunnskólum eftir starfssviðum og kyni 1998-2018. Sótt af https://px.hagstofa.is/pxis/pxweb/is/Samfelag/Samfelag_skolamal_2_grunnskolastig_1_gsStarfsfolk/ SKO02307.px/?rxid=f708b9cd-802b-4d3a-a46d-b39cba18fa91

Hargreaves, A. og Fink, D. (2006). Sustainable leadership. San Francisco: Jossey-Bass.

Harris, A. (2003). Distributed leadership in schools: Leading or misleading? Management in Education, 16(5), 10-13. doi:10.1177/089202060301600504 
Honig, M. I. (2012). District central office leadership as teaching: How central office administrators support principals' development as instructional leaders. Educational Administration Quarterly, 48(733), 732-774. doi:10.1177/0013161X12443258

Ingibjörg Magnúsdóttir. (2013). Að bera sig eftir björginni: Stuðningur við nýja skólastjóra í starfi (óútgefin meistararitgerð). Sótt af http://hdl.handle.net/1946/16897

International Coach Federation. (2018, janúar). Code of ethics. Sótt af https:// coachfederation.org/code-of-ethics Jakob Bjarnar. (2016, 23. mars). Tólf vilja stýra Melaskóla. Visir.is. Sótt af http://www.visir.is/g/2016160329550

Kjarasamningur Sambands íslenskra sveitarfélaga og Kennarasambands Íslands vegna Félags grunnskólakennara. (2018). Sótt af http://ki.is/images/Skrar/FG/Kjaramal/Kjarasamningar/FG_kjarasamningur_i_gildi_011217_ til_300619.pdf

Leadership Thoughts. (2018, október). The difference between coaching and mentoring. Sótt af https:// www.leadershipthoughts.com/difference-between-coaching-and-mentoring/

Lee, L. C. (2015). School performance trajectories and the challenges for principal succession. Journal of Educational Administration, 53(2), 262-286. doi:10.1108/JEA-12-2012-0139

Lög um aðbúnað, hollustuhætti og öryggi á vinnustöðum nr. 46/1980. Sótt af https://www.althingi.is/lagas/ nuna/1980046.html

Lög um grunnskóla nr. 91/2008. Sótt af https://www.althingi.is/lagas/nuna/2008091.html

Lög um jafna stöðu og jafnan rétt kvenna og karla nr. 10/2008. Sótt af http://www.althingi.is/lagas/144a/2008010.html

Lög um persónuvernd og vinnslu persónuupplýsinga nr. 90/2018. Sótt af https://www.althingi.is/lagas/148c/2018090.html

Lög um stöðu íslenskrar tungu og íslensks táknmáls nr. 61/2011. Sótt af http://www.althingi.is/lagas/144a/2011061.html

Marsh, M. (2010). Look sideways: Leaders can learn from critical friends in other organisations. Third Sector, (641), 12-13. Sótt af https://search.proquest.com/docview/851276184?accountid=28822

Maslach, C., Schaufeli, W. B. og Leiter, M. P. (2001). Job burnout. Annual Review of Psychology, 52, 397-422. Sótt af https://search.proquest.com/docview/205845280?accountid=28822

Mendels, P. (2017). Getting intentional about principal evaluations. Educational Leadership, 74(8), 52-56. Sótt af http://search.ebscohost.com/login.aspx?direct $=$ true $\& \mathrm{db}=$ aph\&AN=122879001\&site= ehost-live

Mennta- og menningarmálaráđuneyti. (2013). Aðalnámskrá grunnskóla: Almennur hluti 2011: Greinasvið 2013. Reykjavík: Höfundur.

Meyer, J. M., Macmillan, R. B. og Northfield, S. K. (2011). Principal succession and the micropolitics of educators in schools: Some incidental results from a larger study. Canadian Journal of Educational Administration and Policy, 117, 1-26.

National Policy Board for Educational Administration. (2015). Professional standards for educational leaders. Sótt af http://npbea.org/wp-content/uploads/2017/06/Professional-Standards-for-Educational-Leaders_2015.pdf

OECD. (2014).TALIS 2013 Results:An international perspective on teaching and learning. doi:10.1787/9789264196261en

Ohrt, J. H., Prosek, E. A., Ener, E. og Lindo, N. (2015). The effects of a group supervision intervention to promote wellness and prevent burnout. Journal of Humanistic Counseling, 54(1), 41-58. doi:10.1002/j.21611939.2015.00063.x

Pardini, P. (2000). Critical friends. School Administrator, 57(8), 42. Sótt af https://search.proquest.com/ docview $/ 219251524$ ? accountid $=28822$

Pont, B., Nusche, D. og Moorman, H. (2008). Improving school leadership: Volume 1: Policy and practice. Sótt af https://www.oecd.org/education/school/44374889.pdf

Ragnar F. Ólafsson. (2014). TALIS 2013: Starfsaðstæður, viðhorf og kennsluhœettir kennara og skólastjóra á Íslandi $i$ alpjóðlegum samanburði. Teaching and Learning International Survey. Alpjóðleg samanburðarrannsókn unnin í samvinnu við OECD fyrir mennta- og menningarmálaráðuneytið. Sótt af https://mms.is/sites/mms.is/files/ talis_skyrsla_2014.pdf 
Ragnar F. Ólafsson. (2019). TALIS 2018: Starfshattir og viðhorf kennara og skólastjóra á unglingastigi grunnskóla. Sótt af https://mms.is/sites/mms.is/files/vefutgafa_-_talis_2019.pdf

Retelle, E. (2010). Mentoring experiences of first-year assistant principals. Journal of Educational Administration and Foundations, 21(2), 61-II. Sótt af https://search.proquest.com/docview/896272335?accountid=28822

Reyes, A. (2003). The relationship of mentoring to job placement in school administration. NASSP Bulletin, 87(635), 45-64. Sótt af https://search.proquest.com/docview/216038941 ?accountid=28822

Reykjavíkurborg. (2017, 13. júlí). Nýr skólastjóri við Foldaskóla. Sótt af https://reykjavik.is/frettir/nyr-skolastjori-vid-foldaskola

Service, B., Dalgic, G. E. og Thornton, K. (2016). Implications of a shadowing/mentoring programme for aspiring principals. International Journal of Mentoring and Coaching in Education, 5(3), 253-271. doi:10.1108/ IJMCE-03-2016-0031

Sigríður Margrét Sigurðardóttir. (2018). Stuðningur við skólastjóra í námi og starfi. Netla - Veftímarit um uppeldi og menntun. Sótt af http://netla.hi.is/greinar/2018/ryn/08.pdf

Skólastjóraskipti Ísland - Canada. (2018, október). Um verkefnið. Sótt af https://skolastjoraskipti.weebly.com/ um-verkefnieth.html

Stjórnsýslulög nr. 37/1993. Sótt af http://www.althingi.is/lagas/144a/1993037.html

Swaffield, S. (2004). Critical friends: Supporting leadership, improving learning. Improving Schools, 7(3), 267-278. doi:10.1177/1365480204049340

Upplýsingalög nr. 140/2012. Sótt af http://www.althingi.is/lagas/144a/2012140.html

Whitmore, J. (2017). Coaching for performance: The principles and practice of coaching and leadership (5. útgáfa). London: Nicholas Brealey Publishing.

Sigurbjörg Róbertsdóttir, Börkur Hansen og Amalía Björnsdóttir (2019).

Stuðningur við skólastjóra í grunnskólum: staða og væntingar

Netla - Veftímarit um uppeldi og menntun. Menntavísindasvið Háskóla Íslands.

Sótt af http://netla.hi.is/greinar/2019/ryn/16

DOI: https://doi.org/10.24270/netla.2019.16 